\title{
ARASTIRMA RESEARCH
}

\section{Psikodrama Teknikleri ile Bütünleştirilmiş Etkileşim Grubu Uygulamasının Karşılıklı Bağımlılık Üzerindeki Etkisi}

\author{
Effect of Encounter Group Application Integrated with \\ Psychodrama Techniques on Codependency
}

Yağmur Ulusoy 1 iD, S. Sonay Güçray ${ }^{2}$ (iD

\begin{abstract}
$\ddot{0} \mathbf{z}$
Bu araştırmada psikodrama teknikleri ile bütünleştirilmiş etkileşim grubu uygulamasının karşılıkı bağımlılık üzerindeki etkisini incelemek amaçlanmıştır. Bu araştırmada, karma desenlerden, iç içe desen yöntemi kullanılmıştır. Bu araştırmada ön-test, son-test ve izleme ölçümü yapılan deney ve kontrol grubundan oluşan yarı deneysel bir çalışma yapılmıştır. Araştırmanın çalışma grubu, 14'ü deney, 14'ü kontrol grubuna tesadüfü olarak atanan 28 kadın psikolojik danışman adayından oluşmaktadır. Bu araşıırmanın nicel verilerini toplamak için Bileşik Karşııkı Bağımlıık ölçeği kullanılmış; nitel verileri toplamak için odak grup görüşmesi yapılmıştır. Deney grubuna toplam 14 oturumluk psikodrama teknikleri ile bütünleştirilmiş etkileşim grubu uygulaması yapılmışır. Kontrol grubuna hiçbir işlem uygulanmamıştı. Yapılan analizler sonucunda, nicel bulgular deneysel çalışmanın karşılıklı bağımlıık, kendini feda etme ve duyguları bastırma puanlarını azaltmada etkili olduğunu ortaya koymuştur. Ancak kişilerarası kontrol puanlarını azaltmada etkili olmadığını ortaya koymuştur. Nitel bulguların, nicel bulgularla benzerlik gösterdiği görülmüştür.

Anahtar sözcükler: Karşılıklı bağımlılık, psikodrama, etkileşim grubu.
\end{abstract}

\begin{abstract}
The present study aimed to investigate the impact of encounter group application, integrated with psychodrama techniques, on codependency. In the present study, the nested design method, a mixed design, was utilized. The present study is a quasi-experimental study with control group, where pre-test, post-test and follow-up test measurements were conducted. The study group randomly included 28 female junior and senior pre-service psychological counselors and 14 were included in the control group and 14 in the study group. The quantitative study data were collected with Composite Codependency Scale and focus group interviews were conducted to collect the qualitative study data. An encounter group application, which was integrated with psychodrama techniques, was implemented with the study group for 14 sessions. No intervention was conducted with the control group. As a result of the conducted analyzes, the quantitative findings demonstrated that experimental study was effective in reducing codependency, self-sacrifice and suppression of emotion scores. However, it was not effective in reducing interpersonal control scores. It was found that the qualitative study findings were similar to the quantitative findings.

Keywords: Codependency, psychodrama, encounter group.

\footnotetext{
1 İnönü Üniversitesi, Eğitim Fakültesi Rehberlik ve Psikolojik Danışmanlık Anabilim Dalı, Malatya

${ }^{2}$ Çukurova Üniversitesi, Eğitim Fakültesi Rehberlik ve Psikolojik Danışmanlık Anabilim Dalı, Adana

$\checkmark$ Yağmur Ulusoy, İnönü Üniversitesi, Eğitim Fakültesi Rehberlik ve Psikolojik Danışmanlık Anabilim Dalı, Malatya, Turkey yagmur.ulusoy@inonu.edu.tr

Geliş tarihi/Submission date: 12.09.2019| Kabul tarihi/Accepted: 25.11.2019| Çevrimiçi yayın/Online published: 28.12 .2019
} 
KADINLAR ve erkekler arasındaki ilişkiyi incelemek, geçmişte olduğu gibi günümüzde de araştırmacıların ilgisini uyandırmaktadır. Kadınlar ile erkekler arasındaki ilişkileri etkileyen birçok psikolojik dinamikten söz edilmektedir. Bu dinamiklerden biri olan karşılıklı bağımlılığın çok bilinen bir kavram olmadığı görülmektedir. İlk olarak 1950 ile 1960 yıllar arasında alkolizm danışması alanında ortaya çıkan karşılıklı bağımlılık kavramı (Brown 1994), alkolizmle ilişkilendirilmiştir (Krestan ve Bepko 1990). Bu kavram köken olarak alkolik olan bireylerin, eşleri ile arasındaki işlevsel olmayan ilişkiyi tanımlamak için kullanılmıştır. (Lindley ve ark. 1999). Sonraları bu kavramın içeriği genişleyerek madde bağımlısı olan birinin ilişki kurduğu ve etkilediği diğer insanları (eş, sevgili ya da önemli diğerleri) tanımlamak için kullanılmıştır (Hughes-Hammer ve ark. 1998, Friel ve Friel 2010). Yakın zamana kadar işlevsel olmayan ilişki ve bu ilişkilerin tüm dinamiklerini tanımlamak için kullanılan karşılıklı bağımlılığın (Lindley ve ark. 1999), madde bağımlılığından bağımsız olarak var olduğu görülmüştür (O’Brien ve Gaborit 1992).

Karşılıklı bağımlılık, bir başka kişinin davranışlarının kendisini etkilemesine izin vermek ve o kişinin davranışlarını kontrol etme saplantısı içinde olmak anlamına gelmektedir (Beattie 2012). Karşılıklı bağımlılık, bir başka kişiye ya da bir başka kişi ile kurulan ilişkiye aşırı odaklanarak kimliğini kaybetme sürecini ima etmektedir (Krestan ve Bepko 1990). Karşılıklı bağımlılar; diğerlerinin problemlerine, acılarına, davranışlarına kısaca hayatlarına tepki verirler (Beattie 2012), ilişkide stres ve acı çekmelerine, kötü muameleye maruz kalmalarına rağmen partnerleri ile güçlü bir bağ kurarlar (Noriega ve ark. 2008) ve partnerleri mutsuz olduğunda bile, onların mutsuzluğundan kendilerini sorumlu hissederler. Yani diğerleri için yaşarlar (Morgan 1991, Hogg ve Frank 1992). Bir ilişkide karşılıklı bağımlı davranışların kolayca kabul göreceğini tahmin etmek zor değildir. Ancak bu davranışlar ya da alışkanlıklar kişiyi, yıkıcı ve yürümeyen ilişkilere götürebilir ve o ilişkinin içinde tutabilir (Beattie 2012). Hatta öznel iyi oluşlarını bile sabote edebilir (Reilly 1998). Sonuç olarak karşılıklı bağımlılık, sağlıksız ilişki kuran bireylerin kişilik özelliklerini tanımlamak için kullanılan bir fenomene dönüşmüştür (Bauer 2001).

Teorik olarak erkeklerin de karşılıklı bağımlı olabilme ihtimali söz konusu olmasına rağmen, karşılıklı bağımlılık neredeyse yalnızca kadınlara atfedilmektedir (Anderson 1994). Geleneksel kadınsı cinsiyet rolleri ile karşılıklı bağımlılığın pozitif ilişkili (Roehling ve ark. 1996, Dias 2002, Dear ve Roberts 2002) kadınların karşılıklı bağımlı ilişki kurma olasılıklarının, erkeklere göre daha yüksek olabileceğini akla getirmektedir. Birçok kültürde, kadınlardan erkeklere teslim olmaları ve kendilerini onlara adamaları beklenmektedir (Chodorow 2007). Yani kısacası bağımlı olmaları desteklenmektedir. Bağımlılık, bir sorun olarak değil birliktelik olarak yorumlanmaktadır (Dowling 1994). Karşılıklı bağımlılığın sadece kadınlarla değil aynı zamanda insanlara yardım veren meslek gruplarılya da ilişkilendirildiği görülmektedir.

Psikologlar, hemşireler, aile hekimleri ve sosyal çalışmacıların karşılıklı bağımlılık düzeylerinin yüksek çıkması (Martsolf ve ark. 1999), sadece yardım arayanlar (danışanlar, hastalar vb.) değil, yardımı veren profesyonel kişilerin de karşılıklı bağımlılık riski ile karşı karşıya kaldıklarını göstermektedir. Özellikle işlevsel olmayan ailelerden gelen kadınların, hemşirelik, psikoterapistlik ya da avukatlık gibi insanlara yardım etmeyi esas alan meslekleri tercih etmesinin altında karşılanmamış ihtiyaçların giderilmesinin yattığı 
(Norwood 1993) ve karşılıklı bağımlılık düzeylerinin yüksek çıkmasında köken aile sorunlarının belirleyici olduğu (Martsolf ve ark. 1999) belirtilmektedir.

Kadınların, ruhsal olarak erkeklere göre daha az sağlıklı bulunması (Loring ve Cowan 1997), her dört kadından birinin karşılıklı bağımlılıktan ötürü psikolojik yardım arayışı içerisinde olması (Noriega ve ark. 2008), sorunlu insanları umursayan ve onlarla çalışan kişilerin de karşılıklı bağımlı olma ihtimalinin varlığı (Beattie 2012), kadın psikolojik danışmanların da karşılıklı bağımlılık riski ile karşı karşıya kalabileceklerini akla getirmektedir. Dolayısıyla odağında insanlara yardım etme olan psikolojik danışmanlık mesleğini icra edecek olan kadın psikolojik danışman adaylarının karşılıklı bağımlılıkla mücadelelerinde profesyonel bir yardım almalarının önemi ortaya çıkmaktadır. Literatürde karşlıklı bağımlılıkla mücadele ederken başvurulan profesyonel yardımlar içerisinde ön plana çıkanlar kendine yardım grupları (Bobgan ve Bobgan 1991), grup terapisi (Strakes 1997, Edmundson ve ark. 2000), aile terapisi (Kohlhepp 1998), psikoeğitim (Gemmel 1999), yaratıcı sanat terapisi (Johnson 1990) ve psikodramadır (Mendelsohn 1997). Bu araştırma kapsamında kadın psikolojik danışman adaylarının katıldığ1 psikodrama teknikleri ile bütünleştirilmiş bir etkileşim grubunun karşılıklı bağımlılık üzerindeki etkili olacağ 1 ve örnek bir uygulama niteliği taşıyacağ düşünülmüştür. Ayrıca ülkemizde karşılıklı bağımlılık üzerine yapılan araştırmaların (Ançel ve Kabakçı 2009, Ançel ve ark. 2012, Mukba 2013) betimsel nitelik taşımasından dolayı bu araştırmanın uygulamaya dönük çalı̧̧maların artmasına ön ayak olması umulmaktadır.

\section{Yöntem}

\section{Araştırma Deseni}

$\mathrm{Bu}$ araştırma, nicel ve nitel araştırma yöntemlerinin kullanıldığı karma desenli bir araştırmadır. Karma desenlerden, nitel sonuçların deney sonuçlarının anlaşılırlığını güçlendirmek için sıklıkla başvurulan, iç içe desen yöntemine (Creswell ve Plano-Clark 2014) başvurulmuştur. Bu çalı̧̧manın temel araştırma soruları şunlardır: a) psikodrama teknikleri ile bütünleştirilmiş etkileşim grubuna katılan deney grubu üyelerinin karşılıklı bağımlılık puanlarında anlamlı bir farklılık var mıdır? b) psikodrama teknikleri ile bütünleştirilmiş etkileşim grubuna katılan deney grubu üyeleriyle yapılan odak grup görüşmesinden elde edilen veriler karşılıklı bağımlılık puanlarını nasıl açıklamaktadır?

$\mathrm{Bu}$ araştırmada ön-test, son-test ve izleme ölçümü yapılan deney ve kontrol grubundan oluşan yarı deneysel bir çalışma yapılmıştır. Bu araştırmanın nicel verilerini toplarken psikodrama teknikleri ile bütünleştirilmiş etkileşim grubunun etkililiğini değerlendirmek amacıyla Bileşik Karşılıklı Bağımlılık Ölçeği (Marks ve ark. 2012) kullanılmıştır. Nitel verileri toplarken deney grubuna katılanların psikodrama teknikleri bütünleştirilmiş etkileşim grup sürecine ilişkin görüşlerini almak amaciyla odak grup görüşmesi yapılmıştır. Deneysel çalışma öncesinde hem deney hem de kontrol grubuna Bileşik Karşılıklı Bağımlılık Ölçeği (Marks ve ark. 2012) ön test ölçümlerinin alınması için uygulanmıştır. Sonrasında deney grubu 14 oturumdan oluşan psikodrama teknikleri ile bütünleştirilmiş etkileşim grubuna katılırken; kontrol grubuna ise hiçbir işlem yapılmamıştır. Bileşik Karşılıklı Bağımlılık Ölçeği (Marks ve ark. 2012) hem deney hem de kontrol gruplarına deneysel işlemin bitiminde son test ölçümlerinin; iki ay sonra ise izleme ölçümlerinin alınabilmesi için yeniden uygulanmıştır. Ayrıca deneysel işlemin bitimden hemen sonra deney grubuyla odak grup görüşmesi yapılmıştır. 


\section{Örneklem}

2014-2015 Eğitim Öğretim döneminde İnönü Üniversitesi Eğitim Fakültesi Rehberlik ve Psikolojik Danışmanlık Anabilim dalı üçüncü, dördüncü sınıfa ve yüksek lisans eğitimine devam eden yaşları 20 ile 25 arasında değişen 170 kız öğrenciye Bileşik Karş1lıklı Bağımlılık Ölçeği (Marks ve ark. 2012) araştırmacı tarafından uygulanmış ve açılacak grup hakkında kısa bir bilgi verilmiştir. Toplam 77 öğrenci bu çalışmaya katılmaya gönüllü olduklarını beyan etmiştir. Bu ölçümlerden elde edilen verilerin normal dağılım sergileyip sergilemediğine Kolmogorov-Smirnov değerlerine bakarak karar verilmiştir. Dağılımın normallik varsayımını karşıladığı görülmüştür.

Gönüllü olan, toplam puan ortalamasının bir standart sapma üstünde değer alan 11; gruba model olması için bir standart sapma altında değer alan 3 öğrenci olmak üzere toplam 14 öğrenci deney grubuna; deney grubuna katılma kriterlerini taşıyan 14 öğrenci kontrol grubuna atanmıştır. Deneysel çalışmaya katılan tüm katılımcılar gruplara (deney ve kontrol) tesadüfü örnekleme yöntemiyle atanmıştır. Deney grubuna seçilen 14 öğrenci ile gruba uygun olup olmadıklarına karar vermek ve grup süreci hakkında bilgi vermek için bireysel görüşme yapılmıştır. Bireysel görüşmede gruba geliş amaçlarını öğrenmek ve gruptan beklentileri uygun olmayan, gruba devam edemeyecek olan, psikiyatrik bir tedavi gören ya da başka bir psikolojik yardım alanları gruba dahil etmemek hedeflenmiştir. Görüşmeler tamamlandıktan sonra 14'ü deney, 14'ü kontrol grubuna atanan 28 öğrenci belirlenmiştir.

Deney ve kontrol grubunun ön-test puanları arasında anlamlı bir farklilık olup olmadığının belirlenmesi amacıyla bağımsız gruplar için t-testi uygulanmıştır. Bileşik Karşılıklı Bağımlılık Ölçeğinin Kişilerarası Kontrol alt ölçeği (t=.06, p=.95), Kendini Feda Etme alt ölçeği $(t=1.08, p=-.29)$, Duyguları Bastırma alt ölçeği $(t=.72, p=.47)$ ve toplam puan ortalamaları $(\mathrm{t}=.23, \mathrm{p}=.82)$ arasında anlamlı bir farklılık olmadığı görülmüştür. Deney grubuna seçilen öğrencilerden 7'si üçüncü sınıfta, 6's1 dördüncü sınıfta okumaktadır. Araştırmaya katılan yüksek lisans öğrencileri gruplara katılma kriterlerini karşılamadıkları için hiçbir gruba atanamamıştır.

\section{Ölçekler}

\section{Bileşik Karşılıklı Bağımlılık Ölçeği (BKBÖ)}

Marks ve arkadaşları (2012) tarafından geliştirilen BKBÖ'nün ilk madde havuzu, karşılıklı bağımlılığı ölçen Holyoake Codependency Index (Dear ve ark. 1990), SpannFisher Codependency Scale (Fischer ve ark. 1991), Codependency Assessment Tool (Hughes-Hammer ve ark. 1998) ve Codependent Questionnaire (Roehling ve Gaumond 1996) olmak üzere dört ölçme aracının maddelerinden 28'i seçilerek oluşturulmuştur (Marks ve ark. 2012). 28 maddelik ölçek yaşları 18 ile 70 arasında değişen yaş ortalamaları 35.9 olan toplam 301 yetişkine uygulanmıştır. Uygulanan açıklayıcı faktör analizi sonucunda faktör yükleri .54 ile .75 arasında değişen 19 maddelik ölçeğe ulaşı1mıştır. Üç alt boyutlu, 19 maddelik BKBÖ 1(hiç katılmıyorum) ve 5 (oldukça katılıyorum) arasında derecelendirilen likert tipi bir (Marks ve ark. 2012). BKBÖ’nün Kişilerarası Kontrol Alt Ölçeği, bireyin diğerlerinin davranışlarını kontrol etmeye ve diğerlerinin sorunlarını çözmeye yönelik kendine duyduğu inancı ölçmektedir. BKBÖ'nün Kendini Feda Etme Alt Ölçeği, diğerlerinin ihtiyaçlarını karşılamak için kendi ihtiyaçlarını ihmal etmeyi ölçmektedir. BKBÖ’nün Duygusal Bastırma Alt Ölçeği, bir kişinin 
duyguları kendisini bunaltana kadar onlara ilişkin çok az farkındalığa sahip olma ya da onları bilerek bastırmayı ölçmektedir (Dear Roberts ve Lange 2004).

BKBÖ'nün Türkçe'ye uyarlaması Ulusoy (2015) tarafindan yapılmıştır. Yapılan açıklayıcı faktör analizi sonucunda iki maddenin atılmasına karar verilmiş ve faktör yükleri .36 ile .73 arasında değişen 17 maddeden oluşan bir ölçeğe ulaş1lmıştır. Doğrulayıcı faktör analizi yapıldıktan sonra ölçek maddelerinin faktörlerine .32 ile .86 arasında değişen faktör yükleri ile yüklendiği görülmüştür. Uyum indeksleri $\chi 2 / s d=1.39$, $\mathrm{p}=.00, \mathrm{RMSEA}=.04, \mathrm{SRMR}=.07, \mathrm{GFI}=.91, \mathrm{AGFI}=.88, \mathrm{NFI}=.76$ ve $\mathrm{CFI}=.92$ olarak hesaplanmıştır. Cronbach Alpha iç tutarlılık katsayılarının BKBÖ'nün alt ölçekleri ve toplam puan için .61 ile .76 arasında değişen değerler aldığı; BKBÖ’nün alt ölçekleri ve toplam puan için test tekrar test korelasyon değerlerinin .60 ile .66 arasında değiştiği görülmüştür (Ulusoy 2015).

\section{Yan Yapılandınılmış Görüşme Formu}

Katılımcılardan özgül bilgiler toplamak istendiğinde başvurulan yarı yapılandırılmış görüşmelerin büyük bir kısmı, önceden hazırlanmış açık uçlu sorulardan oluşmaktadır (Merriam 2013). Yarı yapılandırılmış görüşme formu odak grup görüşmesinde kullanılmak üzere araştırmacılar tarafindan geliştirilmiştir. Soruların anlaşılır olup olmadığına ve araştırmaya uygunluğuna karar vermek için uzman görüşüne başvurulmuştur. Uzman görüşü alındıktan sonra nihai forma karar verilmiştir. Bu form deney grubuna katılanların süreçten nasıl etkilendikleri, kendilerini algılayışlarında herhangi bir değişikliğin olup olmadığı ve kendi yaşamlarında neler gözlemlediklerine ilişkin geri bildirim almayı amaçlayan sorular içermektedir. Karşılıklı bağımlılık boyutunda; kendini feda etme, duyguları bastırma ve kişilerarası kontrole ilişkin üç; kendilerini değerlendirme ve gerçek yaşam deneyimleri üzerindeki etkilere ilişkin iki olmak üzere toplam beş açık uçlu soru yöneltilmiştir.

\section{İslem}

Karşılıklı bağımlılığı azaltmayı amaçlayan psikodrama teknikleri ile bütünleştirilmiş etkileşim grubunun oturumları 2014 yılının Ekim ayında başlamış, 2015 yılının Ocak ayında sonlanmıştır. Süreleri 120 dakika ile 210 dakika arasında değişen 14 oturum üyelerin her hafta en az bir, en fazla iki kez toplanması ile gerçekleşmiştir. Tüm uygulamalarda Helsinki bildirgesinde yer alan etik ilkeler göz önünde bulundurulmuştur. Grup üyelerinin izni alındıktan sonra ikinci oturumdan itibaren ses kaydı alınmıştır.

\section{Uygulamanın Kuramsal Çerçevesi}

Etkileşim grupları, kişilerarası iletişim ve ilişkiler aracıllı̆̆ıla kişisel büyüme, gelişim ve ilerlemeye ağırlık vermektedir (Rogers 2003). Etkileşim gruplarında, önceden belirlenmiş amaçlara yer verilmez ve grup lideri üyelerini belli bir yöne yönlendirmektense, üyelerinin duygularını yaşayabileceği ve iletebileceği bir ortam yaratmaya çalışır (Schutz 1994).

Psikodrama 1sınma, eylem ve paylaşım olmak üzere üç aşamadan oluşmaktadır (Karp 2013). Psikodramada sahne, protagonist (danışan), yönetici, terapötik yardımcilar ya da yardımcı egolar ve izleyiciler olmak üzere beş araç kullanmaktadır (Moreno 1946). Etkileşim gruplarının çeşitli tekniklerin kullanılmasına izin verdiği (Schutz 1994) ve psikodrama ya da rol oynama/yapma (role playing) yardımcı bir teknik olarak birçok etkileşim gruplarında kullanıldığı (Lieberman ve ark. 1973) için karşılıklı bağımlılıkla mücadele psikodrama teknikleri ile bütünleştirilmiş etkileşim grubuna başvurulmuştur. 
Tablo 1. Psikodrama teknikleri ile bütünleştirilmiş etkileşim grubu uygulamasının oturum içerikleri

\begin{tabular}{|c|c|}
\hline Oturumlar & Oturumların içerikleri \\
\hline Birinci oturum & $\begin{array}{l}\text { Bu oturumda grup üyeleri birbirleri ile tanışmış, psikodramanın hakkında bilgi verilmiş, grubun } \\
\text { amacı paylaşılmış ve grup kurallarına karar verilmiştir. }\end{array}$ \\
\hline İkinci oturum & $\begin{array}{l}\text { Bu oturumda, üyelerin birbirlerine ve gruba güven duyabilmeleri güven oyunu (ikili eşlemede } \\
\text { göz açık olan üyenin gözü kapalı olan üyeye rehberlik etmesi) oynanmıştır. Bu oyun aracılığıyla } \\
\text { üyelerin grupta olmaktan dolayı yaşadıkları hisleri (kaygı, heyecan, merak vb.) ortaya çıkmıştır. }\end{array}$ \\
\hline Üçüncü oturum & $\begin{array}{l}\text { Bu oturumda grupta duygusal olarak ısınmış bir üyenin protagonist oyununun oynanmasına } \\
\text { karar verilmiştir. Protagonist oyununda diğer insanları (arkadaşları) kontrol etmenin ikili } \\
\text { ilişkilerde yarattığı çatışma ele alınmıştır. Bu oyun aracılığıyla diğer insanlara kendi doğrularını } \\
\text { kabul ettirmenin sağlıkı iletişim kurmayı engellediği fark edilmiştir. }\end{array}$ \\
\hline Dördüncü oturum & $\begin{array}{l}\text { Bu oturumda, sosyal ilişki ağlarına bakmak isteyen bir üyeyle protagonist merkezli bir oyun } \\
\text { oynanmasına karar verilmiştir. Ancak protagonistin diğer insanlar tarafından kabul edilme } \\
\text { isteği ve toplum içinde yanlış bir şey yapma korkusunun ele alındığı bir protagonist oyununa } \\
\text { dönüşsüusşür. Bu oyun aracılığıyla diğer insanların aklından geçenleri okumanın, rahatça } \\
\text { hareket etmeyi engellediği fark edilmiştir. }\end{array}$ \\
\hline Beşinci oturum & $\begin{array}{l}\text { Bu oturumda, üyeler karşılıklı bağımlı ilişkide kurtarıı, zulmeden ve kurban rolleri arasındaki } \\
\text { ilişkiyi temsil eden kırmızı başıklı kız hikayesindeki rolleri (kırmızı başı̧ıklı kız, avcı, babaanne, } \\
\text { kurt gibi) canlandırmış, sonra hikayeyi diledikleri gibi değiştirip aynı rolleri (rolün özelliklerinde } \\
\text { değişiklik yaptıktan sonra) yeniden canlandırmışlardır. Bu oyun aracııığıyla hikayede seçilen } \\
\text { rollerin günlük yaşamdaki rollerle benzerliği olduğu ve bu rollerin esneyebileceği fark edilmiş- } \\
\text { tir. }\end{array}$ \\
\hline Altıncı oturum & $\begin{array}{l}\text { Bu oturumda, bir üyenin gruba devam edip etmeme kararı ve gruba devam kuralının ihlal } \\
\text { edilmesi ele alınmıştır. Ayrıca ısınmış bir üyenin diğer insanlarla güvene dayalı bir ilişki } \\
\text { kuramamasının ele alındığı bir oyun oynanmıştır. Bu oyun aracılığıyla ilişki kurarken ailenin } \\
\text { diğer insanlara güvenilmemesi gerektiği mesajının belirleyici olduğu fark edilmiştir. }\end{array}$ \\
\hline Yedinci oturum & $\begin{array}{l}\text { Bu oturumda, fedakarlık, kontrol ve gizli kalmış duyguların durak isimleri olarak kullanıldığı } \\
\text { grup oyunu oynanmıştır. Bu oyun aracııı̆ıyla tüm üyeler gerçek yaşamlarıyla bu duraklar } \\
\text { arasındaki bağlantıyı ve bu duraklardan nasıl etkilendiklerini incelemişlerdir. }\end{array}$ \\
\hline Sekizinci oturum & $\begin{array}{l}\text { Bu oturumda grup üyeleri sessiz kalmış; ̈̈yelerden önce ikişerli, sonra altışar kişilik gruplara } \\
\text { ayrılıp grupta ihtiyaç duydukları şeyleri paylaşmaları ve en sonunda bireysel olarak tüm gruba } \\
\text { ihtiyaçlarını dile getirmeleri istenmiştir. Bu oturumda üyeler kendilerini açmalarını engelleyen } \\
\text { duygu ve düşüncelerini fark etmişlerdir. }\end{array}$ \\
\hline Dokuzuncu oturum & $\begin{array}{l}\text { Bu oturumda gruptaki sessizlik devam ettiği için "gruptan ne kadar yararlandınız?" sorusunun } \\
\text { bir doğru üzerinde yerleştirme esasına dayanan bir oyun oynanmıstı. Ardından grupta ne olup } \\
\text { bittiğinin haberinin yapılmasına olanak veren grup gazetesi oyunu oynanmıştır. Altıncı } \\
\text { oturumda gruptan ayrılmak isteyen ancak devam etmeye karar veren üyenin kendisini açmak- } \\
\text { tan çekindiği haberi grubun gündemini olmuştur. Bu oturumda kendisini açmaktan duyulan } \\
\text { tedirginliğin konuşulması, grubun sessizliğini bozmasına ve ilerlemesine katkı sağladığı fark } \\
\text { edilmiştir. }\end{array}$ \\
\hline Onuncu oturum & $\begin{array}{l}\text { Bu oturumda, bir önceki oturumda kendini açamadığını dile getiren üyenin diğer üyeler } \\
\text { tarafından yargıladığını düşünmesi, grup içi çatışmaya neden olmuştur. Bu oturumda, grupta } \\
\text { yaşanan çatışmalarla gerçek yaşamdaki çatışmalar arasındaki benzerlik ve çatışmaların yapıcı } \\
\text { bir şekilde çözülebileceği fark edilmiştir. }\end{array}$ \\
\hline On birinci oturum & $\begin{array}{l}\text { Bu oturumda, birkaç oturumdur hiçbir şey hissedemediğini dile getiren üyenin protagonist } \\
\text { oyunu oynanmıştır. Bu oyun aracılığıyla aşıı fedakarlık yapmanın kendi ihtiyaçlarını görmez- } \\
\text { den gelmeye ve bu durumun yoğun öfkeye neden olduğu fark edilmiştir. Bu oturumda iki üye } \\
\text { (üst üste iki oturuma katılmayanların gruba devam etmemesi kuralı gereği) diğer üyeler ve } \\
\text { liderle vedalaşıp, gruptan ayrılımışır. }\end{array}$ \\
\hline On ikinci oturum & $\begin{array}{l}\text { Bu oturumda, babası ile yaşadığı anlaşmazlığı çalışmak isteyen bir üyenin protagonist oyunu } \\
\text { oynanmıştır. Bu oyun aracııığıyla, diğerlerini değiştirme çabasının yorucu olduğu gibi işe } \\
\text { yaramadığı ve kendini değiştirmenin işe yararlığı fark edilmiştir. Ayrıca grubun sonlandırılacağı }\end{array}$ \\
\hline
\end{tabular}




\begin{tabular}{|c|c|}
\hline & $\begin{array}{l}\text { hatırlatılmış ve bir üye daha aynı gerekçeyle (üst üste iki oturuma katılmayanların gruba devam } \\
\text { etmemesi kuralı gereği) gruptan ayrımı̧şı. }\end{array}$ \\
\hline On üçüncü oturum & $\begin{array}{l}\text { Bu oturumda, ilk önce bugünkü ilişkilerde sorunlar yaşanan bir üye; ardından kendi ihtiyaçları } \\
\text { ile diğerlerinin ihtiyaçlarının karşılanması konusunda iç çatışma yaşayan bir üyenin protagonist } \\
\text { oyunu oynanmıştır. Bu oyunlar aracılığıyla, çocukluğunda haksızlığa uğramasına rağmen } \\
\text { kendisine yönelttı̆ği suçluluğu bırakmanın bugünkü duyguları hissetmeyi kolaylaştırdığı ve } \\
\text { diğerlerinin ihtiyaçları ile kendi ihtiyaçlarının karşılanması arasında denge sağlanabileceği fark } \\
\text { edilmiştir. }\end{array}$ \\
\hline On dördüncü oturum & $\begin{array}{l}\text { Son oturumda, grup üyeleri gruptan ayrılmaya ilişkin duygularını paylaşmış; süreç boyunca } \\
\text { neler kazandıkları ve bu kazanımlarla gelecekte ne yapmayı planladıkları bir mektup yazmış- } \\
\text { lardır. Grubun bilmesi/duyması gereken ne varsa söylendiği büyülü ayna oyunu oynanmı̧̧ ve } \\
\text { vedalaşılmış̧ır. }\end{array}$ \\
\hline
\end{tabular}

\section{Oturumlar ve İçerikleri}

Deneysel çalışmanın bazı oturumları sadece etkileşime dayalı olurken; bazı oturumlarında ise etkileşime ek olarak psikodramatik oyunlar oynanmıştır. Deney grubu 11 üye ile sonlandırılmıştır. Kontrol grubuna hiçbir işlem uygulanmamıştır. Tablo 1'de oturumlar ve içeriklerine dair bilgiler yer almaktadır.

\section{Istatistiksel Analiz}

\section{Nicel Analiz}

Deney ve kontrol gruplarından elde edilen nicel veriler SPSS 15.0 istatistik programı kullanılarak analiz edilmiştir. Parametrik bir testin kullanılabilmesi için verilerin en az aralık ölçeğinden elde edilmesi ve normal dağılım sergilemesi gerekmektedir (Can 2014). Deney ve kontrol grubunun ön test, son test ve izleme ölçümlerinin normal dağılım sergileyip sergilemediğine Shapiro-Wilk testi ile bakılmış ve test ortalamalarının normal dağılım sergilediği görülmüştür. Bu nedenle deney ve kontrol gruplarındaki öğrencilerin karşılıklı bağımlılık puanları arasındaki farkın anlamlı olup olmadığına parametrik testlerden tekrarlı ölçümler için iki faktörlü ANOVA ile bakılmıştır.

\section{Nitel Analiz}

Deney grubuyla yapılan odak grup görüşmesinden elde edilen nitel veriler üzerinde içerik analizi yapılmıştır. İçerik analizi, belirli tutarlılıklara ve anlamlara ulaşmak için toplanan nitel materyali nitel veriye indirgeme çabası olarak tanımlanabilir. Içerik analizi ile ulaşılan anlamlar genelde tema olarak isimlendirilir (Patton 2014). Içerik analizinde, kodlama verilerin çözümlenmesi anlamına gelmektedir. Kodlama, verilerin nitelendirilmesi diğer deyişle isimlendirilmesidir (Punch 2014). Içerik analizinin ilk aşamasında veriler kodlanır. Ikinci aşamada, elde edilen kodları belirli kategoriler altında toplayacak temalara ulaşılır. Üçüncü aşamada, veriler kodlar ve temalar altında düzenlenerek sistematik bir çerçeveye ulaşılır (Yıldırım ve Şimşek 2006). Veriler kodladıktan ve temalar belirledikten dışarıdan bir araştırmacının uzman görüşüne başvurulmuştur. Dışarıdan bir denetçinin, araştırmadan elde edilen bulguların doğruluğunu değerlendirmesi nitel araştırmalarda kullanılan geçerlik stratejilerinin biridir (Creswell 2013). Uzman görüşü alındıktan sonra kodlar ve temalar üzerinde gerekli düzenlemeler yapılmıştır.

\section{Bulgular}

Araştırmanın deseniyle paralel olarak, veriler nitel ve nicel bulgular olmak üzere iki başlık altında sunulmuştur. Nicel bulgular başlığında deney ve kontrol grubunun öntest, son-test ve izleme testi ölçümleri üzerinde yapılan istatistiksel analiz; nitel bulgular 
başlığında deney grubuyla yapılan odak grup görüşmesinden elde edilen veriler üzerinde yapılan içerik analizi sonuçları yer almaktadır.

\section{Nicel Bulgular}

Deney ve kontrol gruplarındaki öğrencilerin Bileşik Karşılıklı Bağımlılık Ölçeğinden elde edilen puanlar arasındaki farkın anlamlı olup olmadığına karar vermeden önce, bu puanların aritmetik ortalama ve standart sapma değerleri hesaplanmıştır. Tablo 2'de deney ve kontrol gruplarının Bileşik Karşılıklı Bağımlılık Ölçeği, Kişilerarası Kontrol Alt Ölçeği, Kendini Feda Etme Alt Ölçeği ve Duyguları Bastırma Alt Ölçeği ön-test, son-test ve izleme testi puanlarının aritmetik ortalama ve standart sapma değerleri sunulmuştur.

Tablo 2. Deney ve kontrol gruplarının Bileşik Karşılıklı Bağımlılık Ölçek puanları

\begin{tabular}{|c|c|c|c|c|c|c|c|c|c|c|}
\hline \multirow[t]{2}{*}{ Değişkenler } & \multirow[t]{2}{*}{ Gruplar } & \multicolumn{3}{|c|}{ Ön test } & \multicolumn{3}{|c|}{ Son test } & \multicolumn{3}{|c|}{ İzleme testi } \\
\hline & & $\mathrm{N}$ & Ort. & Ss & $\mathrm{N}$ & Ort. & Ss & $\mathrm{N}$ & Ort. & SS \\
\hline \multirow{2}{*}{$\begin{array}{l}\text { Bileşik Karşılıklı } \\
\text { Bağımlıı Ölçeği } \\
\text { toplam puan }\end{array}$} & Deney & 14 & 55.50 & 8.54 & 11 & 38.54 & 5.08 & 11 & 40.63 & 6.40 \\
\hline & Kontrol & 14 & 54.78 & 7.48 & 14 & 50.64 & 7.93 & 14 & 48.43 & 5.41 \\
\hline \multirow{2}{*}{$\begin{array}{l}\text { Kişilerarası Kontrol Alt } \\
\text { Ölçeğinden }\end{array}$} & Deney & 14 & 15.00 & 2.48 & 11 & 11.63 & 2.29 & 11 & 11.54 & 2.80 \\
\hline & Kontrol & 14 & 15.07 & 3.24 & 14 & 13.35 & 3.07 & 14 & 12.28 & 2.58 \\
\hline \multirow{2}{*}{$\begin{array}{l}\text { Kendini Feda Etme Alt } \\
\text { Ölçeği }\end{array}$} & Deney & 14 & 24.50 & 4.50 & 11 & 16.00 & 2.49 & 11 & 18.00 & 2.68 \\
\hline & Kontrol & 14 & 22.70 & 4.23 & 14 & 21.64 & 5.07 & 14 & 21.36 & 3.50 \\
\hline \multirow{2}{*}{$\begin{array}{l}\text { Duyguları Bastırma Alt } \\
\text { Ölçeği }\end{array}$} & Deney & 14 & 16.00 & 3.53 & 11 & 10.90 & 2.55 & 11 & 10.90 & 2.30 \\
\hline & Kontrol & 14 & 17.00 & 3.76 & 14 & 15.64 & 2.37 & 14 & 15.00 & 2.57 \\
\hline
\end{tabular}

Tablo 2'de görüldüğü gibi deney ve kontrol grubunun Bileşik Karşılıklı Bağımlılık Ölçeği toplam puan, Kişilerarası Kontrol Alt Ölçeği, Kendini Feda Etme Alt Ölçeği ve Duyguları Bastırma Alt Ölçeği son test ve izleme testi puan ortalamalarının ön test puan ortalamalarına göre daha düşük olduğu görülmektedir. Ön-test, son-test ve izleme ölçümleri puan ortalamaları arasındaki farkın anlamlı olup olmadığı tekrarlı ölçümler için iki faktörlü ANOVA ile test edilmiştir. Deney ve kontrol grubunda olmak ile tekrarlı ölçüm faktörlerinin karşılıklı bağımlılık puanları üzerindeki etkileşimsel (ortak) etkilerinin $[\mathrm{F}(2,46)=8.125, \mathrm{p}<.01]$ anlamlı olduğu görülmüştür. Yani deney ve kontrol grubunun karşılıklı bağımlılık puanlarının deney öncesinden sonrasına farklılık göstermiştir. Deney ve kontrol grubunda olmak ile tekrarlı ölçüm faktörlerinin kişilerarası kontrol puanları üzerinde etkileşimsel(ortak) etkilerinin anlamlı olmadığı görülmüştür $[F(2,46)=2.254, p>.05]$. Yani deney ve kontrol grubunun kişilerarası kontrol puanlar1nın deney öncesinden sonrasına farklılık göstermediği görülmüştür. Deney ve kontrol grubunda olmak ile tekrarlı ölçüm faktörlerinin kendini feda etme puanları üzerinde etkileşimsel (ortak) etkilerinin anlamlı olduğu görülmüştür [F(2,46)=13.351, p<.01]. Yani deney ve kontrol grubunun kendini feda etme puanlarının deney öncesinden sonrasına farklılık göstermiştir. Deney ve kontrol grubunda olmak ile tekrarlı ölçüm faktörlerinin duygusal bastırma puanları üzerinde etkileşimsel(ortak) etkilerinin anlamlı olduğu görülmüştür $[\mathrm{F}(2,46)=4.447, \mathrm{p}<.05]$. Yani deney ve kontrol grubunun duygular1 bastırma puanlarının deney öncesinden sonrasına farklılık göstermiştir.

\section{Nitel Bulgular}

Odak grup görüşmesinden elde edilen veriler üzerinde içerik analizi yapılmıştır. Yapılan 
içerik analizi sonucunda duyguları ifade etmeye ilişkin, fedakarlıkta bulunmaya ilişkin, diğerlerini kontrol etmeye ilişkin ve kendisine ilişkin değerlendirmelerinde farklilıklar ile gerçek yaşamları üzerindeki etkileri olmak üzere beş temaya ulaşılmıştır. Bu beş tema deneysel çalışma öncesi ve sonrası karşılaştırılarak ele alınmıştır.

\section{Duygularını İfade Etme Tarzı: Yıkıcılıktan, Yapıcılığa}

Deneysel çalışma öncesinde duyguları ifade etme tarzı teması, yıkıcı bir şekilde ifade etme, ifade edememe ve ifade edebilme olmak üzere üç kategoriye ayrılmaktadır. Katılımcılardan üçü duygularını ifade edemediğini; biri ise yüzeysel bir şekilde ifade ettiğini ve geriye kalan diğerlerinin ise yapıcı bir şekilde ifade ettikleri görülmektedir. Deneysel çalışmanın sonunda duyguları ifade etme tarzlarında olumlu bir değişim olduğu, duyguları ifade etme tarzı ana temasının sadece yapıcı bir şekilde ifade etme kategorisinden oluştuğu görülmüştür. Katılımcıların en sık duygularını karşısındakine saygı duyarak (f.3) ve rahatlık duyarak (f.3) yapıcı bir şekilde ifade ettikleri görülmektedir. Aşağıda duygularını yapıcı bir şekilde ifade etme kategorisini yansıtan bir alıntıya yer verilmiştir:

H.P.'nin oyunundan sonra kendime bakmaya başladım. Küs olduğum arkadaşıma adım attım.

Duygularımı ifade ettim. Ama o bana adım atmadı. Benimle aynı fikirde olmayabilir, buna saygı duydum, bu olgunluğa ulaşabildiğimi fark ettim. (Y.Ç.)

\section{Fedakarlıkta Bulunma: Değişen Duygu ve Düşünceler}

Deneysel çalışma öncesi fedakarlıkta bulunma teması düşünce ve davranışlar olmak üzere iki kategoriye ayrılmıştır. Deneysel çalışma öncesinde katılımcıların çoğunun kendilerini her şeyden sorumlu hissettikleri ve fedakarlığı bir zorunluluk olarak kabul ettikleri gibi düşüncelere; fedakarlık taleplerini reddedememe ve kendilerinden taviz vererek fedakarlık yapma gibi davranışlara sahip oldukları görülmektedir. Katılımcılardan sadece üçü, fedakarlığı az yaptığını ya da yapmadığını belirtmiştir. Deneysel çalışmanın sonunda fedakarlıkta bulunma durumlarında olumlu bir değişim olduğu, fedakarlık bulunma temasının düşüncelerde değişim, davranışlarda değişim ve farkındalıklar olmak üzere üç kategoriden oluştuğu görülmektedir. Katılımcıların kendilerini her şeyden sorumlu hissetmedikleri ve fedakarlık yapmadan da kabul görmeyi bekledikleri şeklinde düşünce değişimleri olduğu görülmektedir. Katılımcıların en sık ifade ettikleri davranı̧̧ değişiminin fedakarlıkta bulunurken seçici davranma (f:3) ve en sık ifade ettikleri farkındalığın aşırı fedakarlık yapmak (f:3) olduğu görülmektedir. Aşağıda öğrencilerin fedakarlıkta bulunma davranışındaki değişim kategorisini yansıtan bir alıntıya yer verilmiştir:

Fedakarlığın karlı olduğu durumları fark ettim....................... Durumların düzeldiği, iyiye gittiği, sonucunda bir şeylere fayda sağladığı oluyor. Ama beni üzdüğü, yorduğu zamanlar da oluyor. Bundan sonra fedakarlık yaparken beni yorduğunda, zora soktuğunda bunu yapmaktan geri durabilmeyi tercih edebiliyorum. (H.K.)

\section{Diğerlerini Kontrol Etme: Değişen ve Değişmeyen Davranışlar}

Deneysel çalışma öncesinde diğerlerini kontrol etme teması davranışlar kategorisinden oluşmaktadır. Katılımcıların en sık ifade ettikleri davranışın diğerlerine yapması gerekeni hatırlatma (f:4) olduğu görülmektedir. Deneysel çalı̧̧manın sonunda diğerlerini kontrol etme temasında değişim olduğu, diğerlerini kontrol etme temasının değişen ve değişmeyen davranışlar olmak üzere iki kategoriden oluştuğu görülmektedir. Diğerlerine karşı ırarcı olma, yapması gerekeni hatırlatma, akıl verme ve uyarma değişmeyen davranışlardır. Bununla birlikte katılımcıların en sık ifade ettikleri davranış değişiminin diğerlerinin tercihlerine saygı duyma (f:3) olduğu görülmektedir. Aşağıda sırasıyla 
diğerlerini kontrol etmede değişen ve değişmeyen davranışlar kategorilerini yansıtan bazı alıntılara yer verilmiştir:

...Mesela işte bir arkadaşım başka bir arkadaşın yatağını toplayacaktı, toplasam sinirlenir mi diyor. Dağınık bırakmış bir de üstüne sinirlenir mi diyor topladığım için. Ben de dedim ki bırak o toplasın. ...O bunu tercih ediyor. Eğer sorumluluğum da değilse, o onun tercihi diyorum. Benim yapacaklarım bu kadarmış diyorum. (R.T.)

Sevdiklerimi kontrol etme ihtiyacı bende hep var. Şöyle onların yapması gereken bir şey var ama yapmıyorlar. Yap yap derim. Mesela sınavına çalışmıyor. Niye çalışmıyorsun, bak çalışmazsan şöyle olur. Bu gruptan önce de vardı, hala da var. (N.K.)

\section{Kendiliğe İlişkin Değerlendirmeler: Olumsuzdan, Olumluya}

Deneysel çalışma öncesinde kendisine ilişkin değerlendirmeler teması olumlu ve olumsuz kendilik özellikleri olmak üzere iki kategoriden oluşmaktadır. Katılımcılardan sadece ikisi olumlu kendilik özelliklerine değinirken, diğerlerinin ise olumsuz kendilik özelliklerine değindikleri görülmektedir. Katılımcıların olumlu kendilik özellikleri olarak kendini güçlü bulma ve kendinden memnun olmayı ifade ettikleri; en sık ifade ettikleri olumsuz kendilik özelliklerinin kuşku duyma ve kolayca kırılma (f:2) olduğu görülmektedir. Deneysel çalışmanın sonunda kendisine ilişkin değerlendirmeler temasında değişim olduğu, sadece olumlu kendilik özellikleri kategorisinden oluştuğu görülmüştür. En sık ifade edilen kendilik özelliğinin kırılmaktan korkmama (f:2) olduğu görülmektedir. Aşağıda olumlu kendilik özellikleri kategorisini yansıtan bir alıntıya yer verilmiştir.

Ben başlarda eleştirilmekten çok korkuyordum. Eleştirilince hemen bozuluyordum. Grubun sonlarına doğru arkadaşlarım bir şeyler söyleyince korkmadığımı fark ettim..............................Eleştirinin o kadar da korkutucu olmadığını fark ettim (T.Ç.)

\section{Gerçek Yaşam Deneyimleri: Fiziksel Sağlık, İletişim ve Kişisel Durum Değişimleri}

Deneysel çalışma öncesinde katılımcıların gerçek yaşam durumlarına ilişkin paylaşımları fiziksel sağlık, iletişim ve kişisel durum olmak üzere üç kategoride toplanmıştır. En sık ifade edilen iletişim durumunun diğerlerini aktif dinlememe (f:2), en sık ifade edilen kişisel durumun akıl okuma olduğu (f:3) ve tek bir katılımcının ise fiziksel sağlık durumu ile ilgili olarak diş gıcırdatmaları ile baş ağrılarına sahip olduğunu ifade ettiği görülmektedir. Deneysel çalışmanın sonunda öğrencilerin gerçek yaşamlarında olumlu değişim olduğu, gerçek yaşam durumlarındaki değişim temasının fiziksel durumda değişim, iletişim durumunda değişim ve kişisel durumunda değişim olmak üzere üç kategoriye ayrıldığ 1 görülmektedir. En sık ifade edilen iletişim durumundaki değişikliğin diğerlerini aktif dinleme, empati becerisini geliştirme ve farklı fikirlere açık olmak (f:2); en sık ifade edilen kişisel durumdaki değişimin akıl okumayı azaltma (f:3) olduğu görülmektedir. Deneysel çalışma öncesinde fiziksel durumu ile ilgili olarak diş gıcırdatmaları ile baş ağrılarına sahip olduğunu belirten tek üye, bu şikayetlerinin azaldığını ifade etmiştir. Aşağıda iletişim durumundaki değişiklik kategorisini yansıtan bir alıntıya yer verilmiştir:

... Karşımdaki insanla empati yapmayı fark ettim. Karşımdaki kişinin yerine geçip, onun yerinden ve rolünden konuştuğumda empati kurmanın zor olduğunu fark ettim. Şuanda karşımdakinin yerine koyuyorum kendimi ve gerçekten kendimi onun yerine nasıl koyabileceğimi öğrendim. Kendi duygularımı, düşüncelerimi hissedebilmeyi, onları ayrıştırabilmeyi beceriyorum.(H.K.) 


\section{Tartışma}

Bu çalışmanın temel amaçlarından biri, psikodrama teknikleri ile bütünleştirilmiş etkileşim grup uygulamasının kadın psikolojik danışman adaylarının karşılıklı bağımlılıkları üzerindeki etkinliğinin belirlenmesidir. Elde edilen sonuçlar, psikodrama teknikleri ile bütünleştirilmiş etkileşim grubuna katılan kadın psikolojik danışman adaylarının, bu gruba katılmayan kadın psikolojik danışman adaylarına göre karşılıklı bağımlılık düzeylerinin önemli düzeyde azaldığını ve bu azalmanın izleme ölçümlerinde de devam ettiğini ortaya koymuştur. Literatür incelendiğinde karşılıklı bağımlılığa müdahale edilirken sıklıkla başvurulan yolun grup terapisi olduğu görülmektedir. Grup terapisinin karşılıklı bağımlılığı azaltmada etkili olduğu (Sheets 1988, Edmundson ve ark. 2000) gibi etkili olmadığını (Strakes 1997) gösteren araştırma bulgularına ulaşılmıştır. Literatürde etkileşim grubunun karşılıklı bağımlılık üzerindeki etkililiğini test eden herhangi bir araştırmaya ulaşılmamıştır. Bu çalı̧̧ma, grup terapisi dışında etkileşim gruplarının da karşılıklı bağımlılık üzerinde etkili olabileceğini göstermiştir.

Elde edilen sonuçlar, psikodrama teknikleri ile bütünleştirilmiş etkileşim grubuna katılan kadın psikolojik danı̧̧man adaylarının, bu gruba katılmayan kadın psikolojik danışman adaylarına göre kişilerarası kontrol düzeylerini önemli düzeyde azaltmada etkili olmadığını ortaya koymuştur. Karşılıklı bağımlı kişinin, kurduğu ilişki son bulsa bile başka biri ile karşılıklı bağımlı ilişkiyi sürdürmeye devam ettiği bilgisi (Beattie 2012), karşılıklı bağımlı ilişkinin sürekliliğini ortaya çıkarmaktadır. Kişilerarası kontrolün, deneysel işlem sonrasında önemli düzeyde bir azalma göstermemesi karşılıklı bağımlı ilişkinin sürekliliğini pekiştiren güçlü bir değişken olabileceğini akla getirmektedir. Karşılıklı bağımlı kadınlar kendilerini çaresiz hissetmektedirler ve çaresizlikle baş ederken mümkün olduğu kadar çevreyi kontrol etmektedirler. Daha fazla kontrol ettikçe, kendilerini daha fazla güvende ve daha az çaresiz hissederler (Reilly 1998). Bu açıklamalar, kadınların kişilerarası kontrolden kolayca vazgeçemeyeceklerini göstermektedir. Ayrıca bu çalışmada kişilerarası kontrol ile ilgili çok az oyunun oynanması ve paylaşımın olması, grup süresinin kişilerarası kontrol değişkeni üzerinde değişim yaratmak için yeterli olmadığını akla getirmektedir.

Elde edilen sonuçlar, psikodrama teknikleri ile bütünleştirilmiş etkileşim grubuna katılan kadın psikolojik danı̧man adaylarının, bu gruba katılmayan kadın psikolojik danışman adaylarına göre kendini feda etme düzeylerinin önemli düzeyde azaldığını ve bu azalmanın izleme ölçümlerinde de devam ettiğini ortaya koymuştur. Bepko ve Krestan'a (1998) göre kadınlara sevgi ve onay kazanmaları için kendilerini tümüyle feda etmeleri gerektiği öğretilmektedir. Kısaca kadınlardan aşırı fedakar olmaları ve bu rolde kalmaları beklenmektedir. Ancak Blatner (2002), rollerin terk edilebileceğini ya da başka rollerle yer değiştirebileceğini belirtmektedir. Kadınların katıldığı bir psikodrama grup çalışması sonucunda, kadınların kadın rolü dışında erkek, baba gibi kendilerine zıt gelen roller oynayarak kadınsı rollerin dışındaki rollerini genişlettikleri ve daha doyumlu kişilerarası ilişkiler yaşadıkları bulgularına ulaşılmıştır (Genç 2006). Baba ve erkek gibi roller, kendini feda etmeyen rolleri temsil ettiği için Genç'in (2006) ulaştı̆̆ bulgular, bu araştırmadan elde edilen bulguları destekler niteliktedir.

$\mathrm{Bu}$ çalışmada, grup üyelerinin aşırı fedakar rolünü ailelerinde öğrendiklerini ve aşırı fedakar rolünü gerektiğinde esnetebileceklerini fark ettikleri hem protagonist hem de grup oyunları sıklıkla oynanmıştır. Bu oyunların, gerek protagonist gerekse yardımcı oyuncu rolünü deneyimleyen grup üyelerinin kendilerini feda etme düzeylerinin azal- 
masında etkili olduğu düşünülmektedir.

Elde edilen sonuçlar, psikodrama teknikleri ile bütünleştirilmiş etkileşim grubuna katılan kadın psikolojik danı̧̧man adaylarının, bu gruba katılmayan kadın psikolojik danışman adaylarına göre duygularını bastırma düzeylerinin önemli düzeyde azaldığını ve bu azalmanın izleme ölçümlerinde de devam ettiğini ortaya koymuştur. Literatür incelendiğinde karşılıklı bağımlılığa müdahalede psikodramadan yararlanılan ve duyguları ifade etme üzerinde etkili olan tek bir çalışmaya ulaşılmıştır. Bu çalışmadan elde edilen bulgular ile psikodramanın karşılıklı bağımlı bireylerin kendilerini ve duygularını açıkça ifade etmeleri üzerinde önemli etkisinin olduğunu gösteren araştırma bulgusu (Mendelsohn 1997) ile benzerlik göstermektedir.

Yalom (2002) etkileşim gruplarında bireylerarası öğrenmenin önemli bir iyileştirici faktör olduğunun altını çizmektedir. Bu çalışmada, grubun üyeler için duygularını rahatlıkla ifade edebilecekleri bir ortam sunduğu, psikodramanın duyguları harekete geçiren bir katalizör olduğu ve bu nedenle psikodrama teknikleri ile bütünleştirilmiş etkileşim grubunun duygularını bastırma üzerinde etkili olduğu düşünülmektedir.

Araştırmanın bir diğer amacı ise psikodrama teknikleri ile bütünleştirilmiş etkileşim grup uygulamasına katılan kadın psikolojik danışman adaylarının karşılıklı bağımlılık puanlarındaki değişimi nasıl açıkladıklarına ilişkin görüşlerinin belirlenmesidir. Psikodrama teknikleri ile bütünleştirilmiş etkileşim grubuna katılan kadın psikolojik danışman adaylarıyla yapılan odak grup görüşmesi sonucunda elde edilen bulguların, nicel bulgularla benzerlik gösterdiği görülmektedir.

Psikodrama teknikleri ile bütünleştirilmiş etkileşim grubuna katılan kadın psikolojik danışman adaylarının diğerlerini kontrol etmeye ilişkin bazı davranışlarının değiştiği bazılarının değişmediği yönündeki geribildirimleri, bu çalışmanın kişilerarası kontrol üzerinde etkili olmadığı nicel bulgusunu tam olarak desteklediği söylenemez. Odak grup görüşmesi sonucunda ulaşılan bulgular, kişilerarası kontrol değişkeninde kısmen bir değişim olduğunu göstermektedir. Aslında kişilerarası kontrol değişkenine ilişkin ulaşılan nicel bulgular, kişilerarası kontrol ölçek puanlarında bir azalma olduğunu ancak bunun anlamlı olmadığını göstermektedir. Bu açıdan bakıldığında, kişilerarası kontrol değişkeninde azalmanın kısmen olduğu nitel bulgusu ile azalma olduğu ancak bunun anlamlı olmadığını gösteren nicel bulgunun birbirleriyle benzerlik gösterdiği söylenebilir.

Psikodrama teknikleri ile bütünleştirilmiş etkileşim grubuna katılan kadın psikolojik danışman adaylarının duygularını yapıcı bir şekilde ifade ettikleri yönündeki geribildirimleri, bu çalışmanın duyguları bastırma üzerinde etkili olduğu nicel bulgusunu destekler niteliktedir. Psikodrama teknikleri ile bütünleştirilmiş etkileşim grubuna katılan kadın psikolojik danışman adaylarının kendilerini feda etmeye ilişkin düşünceleri ile davranışlarının değiştiği ve bu konuda farkındalık kazandıkları yönündeki geribildirimleri, bu çalışmanın kendini feda etme üzerinde etkili olduğu nicel bulgusunu destekler niteliktedir.

Ayrıca psikodrama teknikleri ile bütünleştirilmiş etkileşim grubuna katılan kadın psikolojik danı̧̧man adaylarının gerçek yaşamlarındaki etkilere ilişkin verdikleri geri bildirimler fiziksel sağlık, ilişki kurma ve kişisel durumlarında ve kendilerini değerlendirirken olumlu yönde bir değişimin olduğunu göstermektedir. Kadın psikolojik danışman adaylarının, psikodrama teknikleri ile bütünleştirilmiş etkileşim grubuna katılmanın hem kendilerini olumlu değerlendirmelerine hem de gerçek yaşamları üzerinde 
olumlu etkilere yol açtığı şeklinde verdikleri geri bildirimler, deneysel çalışmanın artı kazanımları olarak yorumlanabilir. Psikodrama sürecinin çok yönlü öğrenmelere (bilişsel, duygusal, davranışsal ve ilişkisel) izin verdiği (Kellermann 2013), insanların sahip oldukları duygusal sorunların çözümüne katkı sağladığı gibi kendilik duygusunu geliştirmeye de yardımcı olduğu (Blatner 2005) ve genel olarak bireyin kendisi ve diğerleri hakkındaki farkındalığında artışa neden olduğu belirtilmektedir (Verhofstadt-Denève 2013). Sonuç olarak elde edilen nicel ve nitel bulgular psikodrama teknikleri ile bütünleştirilmiş etkileşim grubunun karşılıklı bağımlılığı azaltmada etkili olduğunu göstermektedir. Ancak karşılıklı bağımlılığın üç alt boyutundan biri olan kişilerarası kontrol üzerindeki etkisinin anlamlı olmadığ 1 görülmektedir.

Bu araştırma 2014-2015 eğitim öğretim yılında İnönü Üniversitesi Rehberlik ve Psikolojik Danışmanlık Anabilim Dalında okuyan kız öğrencilerle sınırlıdır. Deneysel işlem psikodrama teknikleriyle bütünleştirilmiş etkileşim grubu ile sınırlıdır. Nicel veriler araştırmada kullanılan ölçekten elde edilen verilerle sınırlıdır. Nitel veriler ise araştırma kapsamında yapılan görüşmeden elde edilen verilerle sınırlıdır.

İleride yapılacak grup çalışmalarında uygulayıcılara, katılımcıların kişilerarası kontrol düzeylerini azaltmaya yönelik müdahaleleri içeren oturum sayısının artırılması, deney ve kontrol gruplarına ek olarak plasebo gruplarının eklenmesi ve yardımcı liderin katılımının sağlanması önerilebilir. Ayrıca psikodrama teknikleri ile bütünleştirilmiş etkileşim grup uygulamasının etkililiği daha fazla deneyime sahip olan ebeveynler ve çiftlerden oluşan gruplarda sınanabilir. Araştırmacılara ise karşılıklı bağımlılığın doğasına ilişkin ayrıntılı bilgilere ulaşılması için nitel, kadınlara ek olarak erkeklerin karşılıklı bağımlılık düzeylerinin farklı değişkenlerle ilişkisine bakılabilecek nicel araştırmalar planlamaları önerilebilir. Yurt içinde karşılıklı bağımlılık ile ilgili araştırmaların sayısının yetersiz olduğu dikkate alındığında Türk kültür yapısının karşılıklı bağımlılıkla ilişkisini inceleyen araştırılmaların yapılması önerilebilir. Son olarak Psikolojik Danışman adaylarının lisans eğitimleri sırasında aldıkları uygulamalı derslerde diğerlerini kontrol etme, kendini feda etme ve duygularını bastırma düzeylerine ilişkin farkındalık sağlayacak çalı̧̧malara yer verilmesinin işlevsel olacağı söylenebilir.

\section{Kaynaklar}

Ançel G, Kabakçı E (2009) Psychometric properties of the Turkish form of codependency assessment tool. Arch Psychiatr Nurs, 23:441-453.

Ançel G, Yuva E, Gökmen-Öztuna D (2012) Eş-bağımlıık ve iş yerinde mobing arasındaki ilişki. Anadolu Psikiyatri Derg, 13:104109.

Anderson SC (1994) A critical analysis of concept of codependency. Soc Work, 39:677-685.

Bauer NA (2001) Codependence. Is it a home healthcare concern? Home Healthc Nurse, 19: 432-438.

Beattie M (2012) İlişkilerde Bağımlıı̆̆a Son (Çeviren FN Öztürk). İstanbul, OVVO Basım Yayın ve Dağııım.

Bepko C ve Krestan J (1998) İyi Kadınlar Mutsuz Yaşamlar (Çeviren CE Sılay). İstanbul, İlhan Yayınevi.

Blatner A (2002) Psikodramanın temelleri (Çeviren G Şen). İstanbul, Sistem Yayınclıı.

Blatner A (2005) Psychodrama. Current Psychotherapies. (Eds RJ Corsini, D Wedding):405-438. Belmont, CA, USA.

Bobgan M, Bobgan, D (1991) 12 Steps to Destruction Codependency Recovery Heresies. Santa Barbara, CA, EastGate Puplishers. Brown LS (1994) Subversive Dialogs: Theory in Feminist Therapy. New York, Basic Books.

Can A (2014) SPSS ile Bilimsel Araştırma Sürecinde Nicel Veri Analizi. Ankara, Pegem Akademi Yayıncılık.

Chodorow N (2007) Duyguların gücü: Psikanalizde, Cinsiyette ve Kültürde (Çeviren J Özata-Dirlikyapan). İstanbul, Metis Yayınları.

Creswell JW (2013) Geçerlik ve değerlendirme standartları. Nitel Araştırma Yöntemleri: Beş Yaklaşıma göre Nitel Araştırma ve Araştırma Deseni (Çevirenler M Bütün, SB Demir): 243-268. Ankara, Siyasal Kitapevi.

Creswell JW, Plano-Clark VL (2014) Karma yöntem araştırmalarının doğası. Karma Yöntem Araştırmaları: Tasarımı ve Yürütülmesi 
(Çevirenler Y Dede, SB Demir):1-22. Ankara, Anı Yayıncılık.

Dear GE ve Roberts CM (2002) The relationship between codependency and feminity and masculinity. Sex Roles, 46(suppl 56):159-165.

Dear GE, Roberts CM, Lange L (2004) Defining codependency: A thematic analysis of published definitions. Advances in Psychology, 34:63-79.

Dias M (2002) Deconstructing codependency:The relationship of codependency to feminity and related psychopathological factors (Doctoral dissertation). California, Saybrook Graduate School and Research Center.

Dowling C (1994) Sinderalla Kompleksi: Çağdaş Kadında Bağımsızlık Korkusu (Çeviren S Budak). Ankara, Öteki yayınları.

Edmundson R, Byrne M, Rankin ED (2000) Preliminary outcome data on a model treatment group for codependence. Alcohol Treat Q, 18: 93-107.

Friel J, Friel L (2010) Adult Children: The Secrets of Dysfunctional Families, 2nd ed. Florida, Health Communications.

Gemmel S (1999) A group modality group modality for significant others affected by addiction, an educational/experiential process approach (Master's thesis). Muiitoba, University of Mhitoba Wmnipeg,

Genç M (2006) Karşıyaka toplum merkezinde bir grup kadınla yapılan psikodramatik grup terapisi uygulaması ve rol kuramına göre incelenmesi (Yayınlanmamış Psikodrama Tezi). İzmir, Abdülkadir Özbek Enstitüsü.

Hogg JA, Frank ML (1992) Toward an interpersonal model of codependence and contradependence. J Couns Dev, 70:371-375.

Hughes-Hummer C, Martsolf DS ve Zeller RA (1998) Depression and codependency in women. Arch Psychiatr Nurs, 12:326-334.

Johnson L (1990) Creative therapies in the treatment of addictions: The art of transforming shame. Arts Psychother, 17:299-308.

Karp M (2013) Psikodramaya giriş. Psikodrama Rehberi. (Çevirenler A Büke, Ş Türkdalı):3-13. Ankara, Nobel Akademik Yayınclık.

Kellermann PF (2013) Kuram. Psikodramaya Derinlemesine Bir Bakış: Psikodramanın Terapötik Yönleri. (Çeviren I Gökler Danışman):33- 44. Ankara, Nobel Akademik Yayınclık.

Kohlhepp E (1998) An assesement ant treatment program for individuals in family systems with addiction (Doctoral dissertation). San Diego, United States International University,

Krestan J ve Bepko C (1990) Codependency: The social reconstruction of female experience. Smith Coll Stud Soc Work, 60(suppl 3): 216-232.

Lieberman MA, Yalom I, Miles M (1973) Encounter Groups: First Fact. New York, Basic Book.

Lindley NR, Giordano PT, Hammer ED (1999) Codependency: Predictors and psychometric issues. J Clin Psychol, 55 (suppl 1):5964.

Loring S, Cowan, G (1997) Codependency: an interpersonal phenomenon. Sex Roles, 36: 115-123.

Marks ADG, Blore RL, Hine DW, Dear GE (2012) Development and validation of a revised measure of codependency. Aust J Psychol, 64:119-127.

Martsolf DS, Hughes-Hammer C, Estok P, Zeller RA (1999) Codependency in male and female helping professionals. Arch Psychiatr Nurs, 13(suppl 2):97-103.

Mendelsohn E (1997) The psychodramtist as evolving theorist: reflections on the use of psychodrama and codependence (Psychodrama Thesis). Australia, Australian \&New Zealand Psychodrama Association.

Merriam SB (2013) Nitel Araştırma (Çeviri Ed. S Turan). Ankara, Nobel Yayıncılık

Morgan JP (1991) What is codependency? J Clin Psychol, 47:720-729.

Moreno JJ (1946) Psychodrama and group psychotherapy. Sociometry, 9:249-253.

Mukba G (2013) Üniversite öğrencilerinde ilişki bağımlıı̆ııın bazı değişkenler açısından incelenmesi (Yüksek lisans tezi). Van, Yüzüncü Yıl Üniversitesi.

Noriega G, Ramos L, Medina-Mora ME, Villa AR (2008) Prevalence of codependence in young women seeking primary health care and associated risk factors. Am J Orthopsychiatry, 78:199-210.

Norwood R (1993) Kadın Eğer Çok Severse (Çevirenler H Kanbur, AM Yararbaş). İstanbul, İnkilap Yayınevi.

O'brien PE, Gaborit M (1992) Codependency: A disorder separate from chemical dependency. J Clin Psychol, 48:129-136.

Patton MQ (2014) Nitel Araştırma ve Değerlendirme Yöntemleri (Çevirenler M Bütün, SB Demir). Ankara, Pegem Akademi.

Punch KF (2014) Sosyal Araştırmalara Giriş (Çevirenler D Bayrak, H B Arslan, Z Akyüz). Ankara, Siyasal Kitapevi.

Reilly CE (1998) A cognitive therapy conceptualization of codependency among women. JAddict Nurs, 10:109-114.

Roehling P, Koelbel N, Rutges C (1996) Codependence and conduct disorder: Feminine versus masculine coping responses to abusive parenting practices. Sex Roles, 35:603-618.

Rogers CR (2003) Etkileşim Grupları (Çeviren H Erbil). Ankara, Doruk Yayıncılık.

Rogers CR (2013) Kişi Olmaya Dair (Çeviren A Babacan). İstanbul, Okuyanus Yayıncılık.

Schutz WC (1994) Etkileşimin öğeleri: Özet çeviri. (Çeviren Ö.H. Ersever.) Ankara Üniversitesi Eğitim Bilimleri Fakültesi Dergisi, 27:937-940. 
Sheets CH (1988) Co-dependency and the healing process (Doctoral dissertation). Ann Arbor, Union Graduate School.

Strakes C (1997) Cognitive group therapy program for codependent women: Development and effects on self- esteem, depression and coping skills (Doctoral dissertation). Columbia, Columbia University.

Ulusoy Y (2015) Psikodrama teknikleri ile bütünleştirilmiş etkileşim grubu uygulamasının karşsılıklı bağımlılık üzerindeki etkisi (Doktora tezi). Adana, Çukurova Üniversitesi.

Verhofstadt-Denève L (2013) Varoluşcu-diyalektik psikodrama. In Psikodrama: Kuram ve Uygulamadaki Gelişmeler. (Çeviri Ed. I Doğaner ):103-117. Ankara, Nobel Yayıncilık.

Yalom I (2002) Grup Psikoterapisinin Teori ve Pratiği (Çevirenler A Tangör, Ö Karaçam). İstanbul, Kabalıı Yayınevi.

Yıldııım A, Şimşek H (2006) Sosyal Bilimlerde Nitel Araştırma Yöntemleri, 6. Baskı.Ankara, Seçkin Yayıncılık.

Yazarların Katkıları: Tüm yazarlar, her bir yazarın çalışmaya önemli bir bilimsel katkı sağladığını ve makalenin hazıılanmasında veya gözden geçirilmesinde yardımcı olduğunu kabul etmişlerdir.

Etik Onay: Çalışma Yerel Etik Kurul tarafından onaylanmıştır. Tüm katılımılardan yazılı aydınlatılımış onam alınmıştır.

Danışman Değerlendirmesi: Dış bağımsız

Çıkar Çatışması: Yazarlar çıkar çatışması bildirmemiştir.

Finansal Destek: Bu çalışma Çukurova Üniversitesi Bilimsel Araştırma Projeleri Koordinasyon Birimi (SDK- 2014-2357)tarafından desteklenmş-

tir.

Yazarın Notu: Bu çalışma 1. Yazarın doktora tezinin bir kısmından oluşmaktadır. Bu çalışma 9-11 Nisan 2015 tarihinde Adana'da düzenlenen I.

Uluslararası Çukurova Kadın Çalışmaları Kongresinde sözlü bildiri olarak sunulmuştur.

Teşekkür: Bu makalenin İngilizce metnini değerlendiren Efe MORAL'a teşekkür ederiz.

Authors Contributions: All authors attest that each author has made an important scientific contribution to the study and has assisted with the drafting or revising of the manuscript.

Ethical Approval: The study was approved by the Local Ethics Committee. Written informed consent was obtained from all participants.

Peer-review: Externally peer-reviewed.

Conflict of Interest: No conflict of interest was declared by the authors.

Financial Disclosure: This study was supported by Cukurova University Scientific Research Projects Coordination Unit (SDK-2014-2357).

Author's Note: This study consists of a part of the author's doctoral thesis. This study was presented as an oral paper at the 1st International Cukurova Women's Studies Congress held on 9-11 April 2015 in Adana.

Acknowledgement: We would like to thank Efe MORAL for evaluating the English text of this article. 